\title{
Toxina botulínica y su empleo en la patología oral y maxilofacial
}

\section{Botulinum toxin and its use in oral and maxillofacial pathology}

\author{
D. Martínez-Pérez
}

Resumen: Las toxinas botulínicas son exotoxinas de la bacteria formadora de esporas Clostridim botulinum y los agentes causantes del botulismo. Cuando se inyecta en el músculo produce una parálisis flácida. El efecto clínico está directamente relacionado con la dosis y debe ajustarse para cada caso concreto. La Toxina botulínica ha demostrado en los más de veinte años en que se está utilizando que es un fármaco seguro. Las indicaciones de la toxina botulínica en la actualidad incluyen todas aquellas patologías que resultan de la hiperfunción muscular y la disfunción autonómica.

Palabras clave: Clostridium Botulinum; Toxina botulínica; Distonía; Hipertrofia maseterina; Bruxismo.

\section{Antecedentes historicos}

En 1895 se aisló por primera vez el microbio Clostridium Botulinum, en Bélgica por van Emengem. Durante la segunda guerra mundial $y$, ante el peligro de que la toxina botulínica se generalizase como arma biológica, el gobierno de los EEUU asignó un número de científicos a su estudio en Fort Detrick en Maryland. ${ }^{1}$ Fueron éstos los que lograron purificar en su forma cristalina el subtipo A (Botox) y, del mismo modo, la forma inglesa Dysport fue también fruto de investigaciones en armas biológicas. La primera aplicación clínica fue descrita por Scott y cols que investigaban en primates la posibilidad de un tratamiento no quirúrgi-

Unidad de Cirugía Oral y Maxilofacial.

Fundación Jiménez Díaz, Madrid, España.

Correspondencia:

Dolores Martínez-Pérez

Fundación Jiménez Díaz

Avda. de los Reyes Católicos, 2

28040 Madrid
Abstract: Botilinum toxins are exotoxins of the bacteria that form the Clostridium botulinum spores and the causative agents of botulism. When injected into the muscle flaccid paralysis is produced. The clinical effect is directly related with the dose and is should be adjusted for each particular case. over the last twenty years that it has been in use, the botulinum toxin has shown itself to be a reliable drug. Current indications for the use of botulinum toxin include all those pathologies which are the results of muscle hyperfunction and autonomic dysfunction.

Keywords: Clostridium Botulinum; Botulinum toxin; Dystonia; Masseteric hypertrophy; Bruxism.

\section{Historical background}

In 1895 for the first time the Clostridium Botulinum was isolated in Belgium by van Emengem. As there was a danger during the Second World War that the botulinum toxin could be used widely as a biological weapon, the US government appointed a group of scientists to study it in Fort Detrick in Maryland. 1 They were the ones that were able to purify Subtype A (Botox) in its crystalline form and, by the same token, the English form Dysport was produced as a result of investigations into biological weapons. The first clinical application was described by Scott and cols. who were investigating with primates the possibility of non-surgical treatment for strabismus in 1977, and the first publication of its use as a therapeutic agent in humans took place in 1980.2 The use of the toxin for cosmetic purposes was observed by chance by the Carruthers husband and wife team who noted a reduction in the wrinkles of the glabella in a patient they had treated with blepharospasm. As a result of this they began to treat patients with purely cosmetic aims. $^{3}$ 
co para el estrabismo en 1977, y la primera publicación de su uso como agente terapéutico en humanos tuvo lugar en 1980.² El uso de la toxina con fines cosméticos surgió de una observación casual realizada por el matrimonio Carruthers que notaron una reducción en las arrugas de la glabela en un paciente al que habían tratado por blefarospasmo. A partir de este hecho comenzaron a tratar pacientes con fines puramente cosméticos. ${ }^{3}$

\section{Estructura y farmacología}

Las toxinas botulínicas son exotoxinas de la bacteria formadora de esporas Clostridim botulinum y los agentes causantes del botulismo. La clínica del botulismo incluye disfunción autonómica (sequedad de boca, nausea, íleo paralítico, hipotensión postural), y parálisis flácida sin fiebre.

Es una sustancia altamente tóxica a dosis letales de $10-9 \mathrm{~g} / \mathrm{kg}$ de peso. Existen ocho serotipos (A, B, C alpha, C beta, D, E, F y G). De éstas $A, B$ y $E$ son las que se asocian con el botulismo en humanos. Los serotipos son parecidos desde el punto de vista estructural y funcional, sin embargo tienen receptores propios, y lugares intracelulares enzimáticos propios.

Cuando se inyecta en el músculo produce una parálisis flácida. La toxina se liga a las terminaciones nerviosas colinérgicas, penetra en la célula por endocitosis mediada por un receptor y pasa al citoplasma donde actúa escindiendo una de las tres proteínas necesarias para la exocitosis de la acetilcolina. Según el serotipo de que se trate actuará sobre una proteína determinada o en sobre enlaces distintos. Esto determina la duración del efecto de las distintas toxinas botulínicas. La BTA inactiva la proteína SNAP-23 y BTB la VAMP.4,5 Las fibras musculares sufren así una denervación funcional, lo que resulta en una parálisis flácida. El comienzo del efecto tiene lugar unas 6-36 horas tras la inyección, el efecto máximo tiene lugar a los 7-14 días. En el plazo de 3-6 meses se restablece la función muscular debido a la formación de nuevos brotes axonales y uniones neuromusculares. El efecto clínico esta directamente relacionado con la dosis y debe ajustarse para cada caso concreto. El uso repetido a largo plazo parece que no da lugar a atrofia ni a la degeneración muscular permanente. ${ }^{6}$

La toxina botulínica A se obtiene en el mercado en dos preparados. BOTOX (Allergan) y Dysport (Ipsen Ltd., UK). Posteriormente se ha comercializado un preparado de toxina B, Myoblock (Elan Pharmaceuticals San Francisco, Ca) que se encuentra aceptado por la FDA para su uso en distonías cervicales. ${ }^{7}$ En EE.UU., la toxina BTA se presenta en viales de $100 \mathrm{U}$ en forma de toxina cristalina purificada y al vacío (Botox). Una unidad se define como la dosis media letal intraperitoneal para ratones Webster suizos (LD50). ${ }^{8}$ La dosis letal media en humanos es de 2800-3500 U.

La preparación europea de la toxina botulínica A Dysport, (Ipsen Ltd., antes Speywood pharmaceuticals, Maidenhead, UK) no es equivalente en sus dosis, debido a un método distinto en la purificación. Habitualmente las dosis requeridas de Dysport para un mismo efecto son de dos a cinco veces mayor que la de Botox. ${ }^{9}$ La reconstitución de la toxina botulínica A (Botox) se lleva a cabo con suero salino sin conservantes. No se debe agitar vio-

\section{Structure and pharmacology}

Botulinum toxins are exotoxins of the bacteria that form the Clostridium Botulinum spores and the causative agents of botulism. Clinical diagnosis of botulism includes autonomic dysfunction (dryness of the mouth, nausea, paralytic ileus, postural hypertension and flaccid paralysis with no fever. It is a highly toxic substance, lethal doses being $10-9 \mathrm{~g} / \mathrm{kg}$ of weight. There are eight serotypes $(A, B, C$ alpha, $C$ beta, $D, E, F$ and $G$ ). Of these $A, B$ and $E$ are those associated with botulism in humans. The serotypes are similar from a structural and functional point of view, however they have their own receptors, and their own intracellular enzymatic areas.

When injected into the muscle flaccid paralysis is produced. The toxin attaches itself to the cholinergic nerve terminations, it penetrates the cell by means of endocytosis aided by a receptor and it passes into the cytoplasm where it acts by separating one of the three proteins necessary for exocytosis of the acetylcholine. Depending on which serotype it is, it will act on a certain protein or on different bonds. This determines the duration of the effect of the different botulinum toxins. The BTA deactivates the SNAP-23 protein and BTB the VAMP.4,5 The muscle fibers then suffer functional denervation which results in flaccid paralysis. The effect starts 6-36 hours after the injection, and the maximum effect is 7-14 days later. In the space of 3-6 months muscular function is reestablished due to the formation of new axonal sprouting and neuromuscular unions. The clinical effect is directly related with the dose and it should be adjusted for each particular case. Long-term use does not seem to give rise to atrophy nor to permanent muscular degeneration. ${ }^{6}$

Botulinum toxin type $A$ can be found on the market in two forms. BOTOX (Allergan) and Dysport (Ipsen Ltd., UK). Later a Toxin type B preparation was marketed, Myoblock (Elan Pharmaceuticals San Francisco Ca.) which has FDA approval for use in cervical dystonia. ${ }^{7}$ In the US the BTA toxin comes in $100 \mathrm{U}$ vials in the form of vacuum dried, purified crystalline toxin (Botox). A single unit is defined as the average lethal intraperitoneal dose for Swiss Webster mice (LD50).8 The average lethal dose in humans is 2800-3500U.

The European preparation of the Botulinum toxin type A Dysport, (Ipsen Ltd., previously Speywood pharmaceuticals, Maidenhead, UK) does not have an equivalent dose, due to there being a different method for purification. Generally, the dose required of Dysport for the same effect is two to five times greater than Botox. ${ }^{9}$ The reconstitution of the botulinum toxin type $A$ (Botox) is carried out with saline with no preservatives. It should not be shaken, nor frozen as freezing causes denaturation of the solution. The volume of dilution varies, between 1 to $8 \mathrm{ml}$ for every 100U. (Allergan Inc, prospectus for the use of Botox). The reconstituted solution should be kept at between 2 and $8^{\circ} \mathrm{C}$, and using the solution within the first four hours is recommended. 
lentamente, ni congelar, ya que la congelación desnaturalizaría la solución. El volumen de dilución es variable, entre 1 a $8 \mathrm{ml}$ por 100 U. (Allergan Inc, prospecto para utilización de Botox) La solución reconstituida debe almacenarse entre los 2 y $8^{\circ} \mathrm{C}$, y se recomienda la utilización de la solución en las primeras 4 horas.

\section{Efectos adversos y complicaciones}

La toxina botulínica ha demostrado en los más de veinte años en que se está utilizando que es un fármaco seguro si bien existen al menos tres artículos que presentan la producción de un síndrome botulínico. ${ }^{10-12}$

Dentro de los efectos sistémicos producidos por la toxina botulínica es frecuente la presencia de síntomas pseudogripales (nausea, cansancio, erupciones cutáneas a distancia). Ultimamente, la aparición de sed se ha asociado con estos tratamientos, siendo este efecto algo más intenso con la utilización de la toxina B que con la A. ${ }^{13}$ Otro efecto a distancia de la toxina es que produce un enlentecimiento del vaciado de la vesícula biliar y, en alguna ocasión, se ha descrito la aparición de un cólico biliar. ${ }^{14}$

En la zona de la inyección aparece con frecuencia dolor, eritema, equímosis o hiperestesia de corta duración. La difusión de la toxina y la paralización de grupos musculares adyacentes representa el efecto adverso más frecuente. Con el fin de minimizar este problema se recomienda utilizar diluciones concentradas e inyecciones múltiples, así como cuidar al máximo la localización y la profundidad de la inyección. En cualquier caso, el efecto adverso al igual que el terapéutico, es reversible.

Está contraindicado el tratamiento con toxina botulínica en caso de que exista una enfermedad neuromuscular (miastenia, síndrome de Eaton Lambert), y con tratamientos con aminoglucósidos, penicilamina, quinina, y bloqueantes de los canales del calcio, ya que éstos pueden potenciar sus efectos.

La resistencia adquirida a la toxina botulínica es un hecho sobradamente conocido. Aparece en un 3-5\% de los pacientes tratados por distonía cervical. Se debe a la aparición de anticuerpos circulantes cuyo desarrollo parece correlacionarse con la duración del tratamiento, dosis total alcanzada y repetición del tratamiento en intervalos cortos. En general, se recomienda una dosis máxima de $100 \mathrm{U}$ por sesión y, con un espacio de tiempo entre sesiones de al menos tres meses. En los casos de resistencia a la toxina A, algunos pacientes responden al tratamiento con Toxina $B$ inicialmente. Al cabo de varias sesiones se desarrolla también resistencia que se explica como el desarrollo de anticuerpos contra el nuevo serotipo o como antigenicidad cruzada. ${ }^{15}$

\section{Utilización clínica}

Las indicaciones de la toxina botulínica en la actualidad incluyen todas aquellas patologías que resultan de la hiperfunción muscular y la disfunción autonómica. En 1989 se aprobó su uso por la FDA para el tratamiento de estrabismo, blefarospasmo y alteraciones de VII par, en Abril de 2002 se aprobó la utilización de la toxi-

\section{Adverse effects and complications}

Over the last twenty years that it has been in use, the botulinum toxin has shown itself to be a reliable drug, although there are at least three articles reporting the appearance of a botulism-like syndrome. . $^{10-12}$

Among the systemic effects produced by the botulinum toxin, flue-like symptoms are frequent (nausea, fatigue, separated skin rashes). Lately, thirst has been associated with these treatments, although the effect is more intense with the $B$ toxin than with the A. ${ }^{13}$ Another effect of toxin at a separated is that the emptying of the gallbladder slows down, and on some occasions bilary colic has been reported..$^{14}$

In the area of the injection pain, erythema, ecchymosis, or hyperesthesia of short duration frequently appear. The diffusion of the toxin and the paralysis of adjacent muscle groups is the most common adverse effect. In order to minimize these problems, the use of concentrated dilutions and multiple injections are recommended, as well as taking maximum care as to the location and depth of the injection. In any event, the adverse effect as well as the therapeutic effect is reversible.

Botulinum toxin treatment is not advised if there is a neuromuscular illness (myasthenia, Eaton Lambert syndrome) or treatment with aminoglycoside, penicillamine, quinine, and calcium channel blockers, as these can increase the effects.

Acquired resistance to botulinum toxin is extremely well known. It appears in 3-5\% of patients treated for cervical dystonia. This is due to the appearance of circulating antibodies that seem to develop depending on the length of treatment, dose reached and repetition of the treatment after short intervals. In general a maximum dose of 100 u per session is recommended, together with a three-month interval between sessions. In cases of resistance to the A Toxin, some patients initially respond to treatment with the $B$ Toxin. After several sessions resistance is also developed which is because of the development of antibodies against the new serotype or crossed antigenicity. ${ }^{15}$

\section{Clinical Use}

Current indications for the use of botulinum toxin include all those pathologies which are the result of muscle hyperfunction and autonomic dysfunction. In 1989 it received FDA approval for the treatment of strabismus, blepharospasm and alterations VII carnial nerve. In April 2002 Botulinum toxin $A$ was approved by the FDA $A^{16}$ for cosmetic treatment of the glabella, and this year its use in cosmetic treatment has been approved in Spain.

\section{Dystonia}

The first applications of the botulinum toxin in our specialty have been in the treatment of patients with focal dystonia (orbicularis oculi, facial, oromandibular and myoclonus of the palate dystonia). 
na botulínica A para el tratamiento cosmético de la glabela por la FDA ${ }^{16}$ y este mismo año ha sido aprobada en España su utilización para tratamientos cosméticos.

\section{Distonía}

Las primeras aplicaciones de la toxina botulínica en nuestra especialidad han tenido lugar en el tratamiento de pacientes con distonías focales (distonía orbicularis oculi, facial, oromandibular, mioclonias palatinas).

\section{Distonía oromandibular}

Según el tipo de movimiento generado en cada caso de dístonía, el tratamiento se dirige hacia los grupos musculares implicados (de apertura oral, de cierre oral, de protrusión lingual, etc.). En términos generales, hoy en día se suele evitar la inyección de los vientres anteriores de los músculos digástricos y de los músculos linguales ya que la paralización de los músculos linguales resulta en disfagia y disartria. ${ }^{17}$ La inyección de los músculos pterigoideos internos, temporales y maseteros se realiza de forma directa, dado el gran volumen de los mismos. No ocurre así con los músculos pterigoideos externos, más difíciles de localizar para los que se recomienda su identificación por medio de electromiografía. Se intenta minimizar la aparición de insuficiencia velofaríngea que puede aparecer por la difusión de la toxina (Figs. 1 y 2).

\section{Distonías cervicales y faciales}

Una de las primeras indicaciones aceptadas fue el tratamiento del blefarospasmo. Para minimizar los efectos secundarios en el tratamiento del blefarospasmo es recomendable mantener las inyecciones por fuera del reborde orbitario con el fin de evitar alterar la función de la glándula lacrimal, la función de bombeo del sistema lacrimal, el músculo elevador del párpado y los músculos oculomotores.

Del mismo modo, se ha utilizado en el tratamiento del espasmo hemifacial, de las sinquinesias que aparecen en la recuperación de la paresia facial y muy extensamente en el tratamiento del torticollis. En esta patología, la toxina es efectiva siempre y cuando de tenga un conocimiento anatómico y neurofisiológico de los músculos involucrados. Se incluyen el esternocleidomastoideo, trapecio, semiespinalis capitis, esplenio de la cabeza, elevador de la escápula y músculos paraespinales menores. ${ }^{1}$

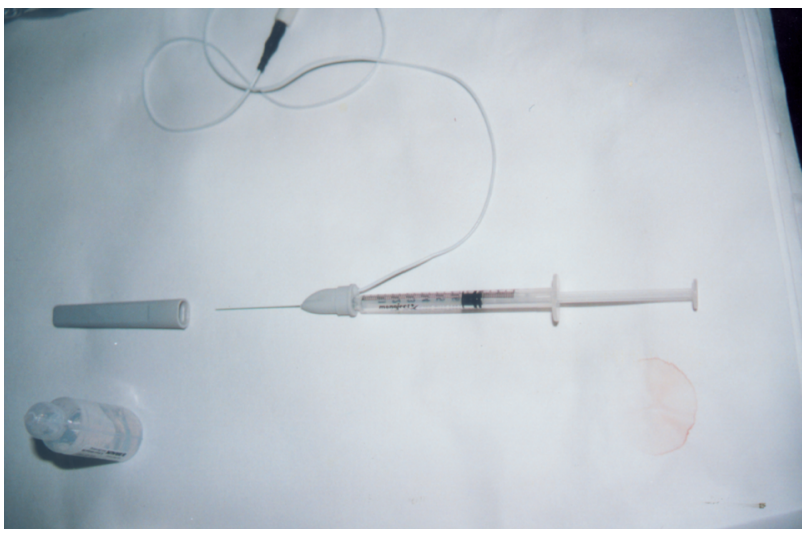

Figura 1. Material de punción.

Figure 1. Puncture instruments.

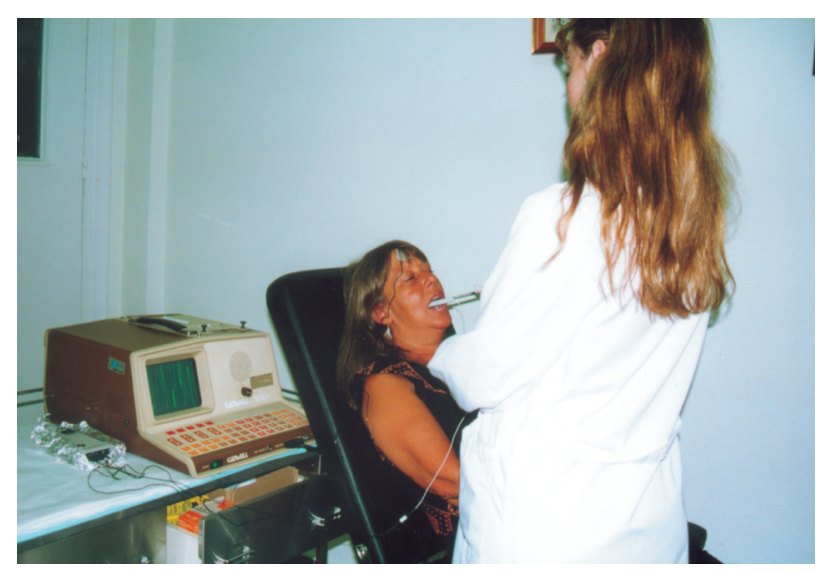

Figura 2. Control electromiográfico. Figure 2. Electromyographic control.
Oromandibular dystonia Depending on the type of movement generated in each case of dystonia, treatment is directed at the group of muscles implicated (oral aperture, oral closure, lingual protrusion, etc.) Generally, injecting the anterior bellies of digastric and lingual muscles is avoided today as the paralysis of lingual muscles leads to dysphagia and dysarthria. ${ }^{17}$ Injecting the internal pterygoid, temporal and masseter muscles is done directly given their large volume. This is not the case with the external pterygoid muscles which are more difficult to locate. Identification using electromyography is recommended. The onset of velopharyngeal insufficiency because of diffusion of the toxin should be minimized.

\section{Cervical and facial \\ dystonia}

One of the first treatments to be accepted was for its use in blepharospasm. In order to minimize the secondary effects in blepharospasm treatment, the injection should be kept outside the orbit border so as not to affect the function of the lacrimal gland, the pumping function of the lacrimal system, the lid elevator muscle nor the oculomotor muscles.

Similarly it has been used in the treatment of hemifacial spasms, in adherences that appears during recuperation of facial paresis and, extensively, in the treatment of torticollis. In this pathology the toxin is effective only if there is anatomical and neurophysiological knowledge of the muscles involved. Included are the sternocleidmastoideus, trapezius, semispinalis capitis, splenius capitis, scapula elevator and minor paraspinal muscles.

\section{Cosmetic Usage}

The botulinum type A toxin has been used, since first described by Carruthers, for the treatment of facial wrinkles. Its use has extended particularly in the treatment of forehead wrinkles, in the glabella area, external lines of the canthus (crows feet), as well as for modifying the position of the eyebrows. It is less used in the middle and lower third of the face where it has been used to change the nasolabial angle, 


\section{Usos cosméticos}

La toxina botulínica A se utiliza desde la descripción inicial de Carruthers para el tratamiento de las arrugas faciales. Su uso se ha extendido sobre todo para el tratamiento de las arrugas frontales, de la región de la glabela, líneas cantales externas (patas de gallo), así como para modificar la posición de las cejas. Es menos frecuente su uso el los tercios medio e inferior de la cara donde también se ha utilizado para variar el ángulo nasolabial, generar un efecto de aumento del labio superior, y tratar las arrugas peribucales entre otras aplicaciones. ${ }^{18,19}$

\section{Hipertrofia maseterina}

Esta aplicación se describió por primera vez en 1994 y desde entonces se ha extendido de manera asombrosa, especialmente en Corea. ${ }^{20-22}$

Patología de la articulación temporomandibular

En la literatura aparecen cada vez mas aplicaciones de la toxina botulínica para el tratamiento de mialgias masticatorias, bruxismo, luxación recidivante de mandíbula. ${ }^{23}$

\section{Cefaleas tensionales}

A comienzos de la década de 1990, Binder notó que los pacientes con migrañas o cefaleas tensionales que recibían toxina botulínica para usos cosméticos sentían mejoría o desaparición de las mismas. ${ }^{24}$ Más tarde estos hallazgos han sido refrendados por ensayos clínicos. ${ }^{25}$

\section{Sistema autonómico}

La acetilcolina no sólo es el principal neurotransmisor muscular sino también del sistema periférico parasimpático. En este sentido se ha utilizado en la modulación de la salivación y la sudoración. Resulta efectivo para el tratamiento del síndrome de Frey, ${ }^{26}$ y proporciona alivio a aquellos pacientes aquejados de problemas neurológicos (ELA; Parkinson, parálisis cerebral) con hipersialorrea. ${ }^{27}$ Del mismo modo, se ha introducido para el tratamiento de la hiperhidrosis y de la rinorrea. ${ }^{28}$

\section{Otros}

Entre las indicaciones mas novedosas se encuentra la consecución de cicatrices más estéticas disminuyendo la tensión de las heridas al inyectar los márgenes de una herida con toxina. ${ }^{29}$

\section{Futuro}

Las limitaciones fundamentales de la toxina botulínica provienen de la vida media de su efecto terapéutico. El tratamiento de patologías crónicas requiere la repetición de los tratamientos cada tres meses de por vida, lo que no sólo resulta molesto sino que favorece la aparición de resistencias. El futuro deseable de estas terapéuticas requiere la obtención de preparados con distinta duración de los efectos. Es de esperar que con el tiempo se obtengan preparados con efectos de larga duración. for creating the effect of a fuller top lip, and for the treatment of peribuccal lines among other applications.18,19

Masseteric hypertrophy

Application in this area was first described in 1994, and from then its use has extended astonishingly, especially in Korea. ${ }^{20,21,22}$

Pathology of the temporomandibular joint In the literature there are more and more applications of botulinum toxin for the treatment of masticatory myalgias, bruxism, recurrent dislocation of the jaw. ${ }^{23}$

Tension headaches

At the beginning of the 1990s decade Binder noted that patients with migraines or tension headaches that had received botulinum toxin for cosmetic purposes, experienced relief or disappearance. ${ }^{24}$ These findings were later endorsed by clinical trials.

\section{Autonomous system}

Acetylcholine is not only the principal neurotransmitter of the muscles but also of the peripheral parasympathetic system. In this sense it has been used in salivation and sweating modulations. It is effective in the treatment of Frey syndrome and it gives alleviation to those patients suffering neurological problems (ELA; Parkinson's, cerebral paralysis) with hypersialorrhea. ${ }^{27}$ In the same fashion it has also been introduced for the treatment of hyperhidrosis and rhinorrhea. ${ }^{28}$

Others

Among the more novel indications is the obtaining of more aesthetic scarring by reducing the tension of the wound on injecting the edges with toxin. ${ }^{29}$

The future

The fundamental limitations of the botulinum toxin are due to the average duration of its therapeutic effect. Treatment of chronic pathologies requires the repetition of treatment every three months throughout the patient's lifetime, which is not only bothersome but it also favors the appearance of resistances. The desirable future of these therapies requires obtaining preparations with effects of differing length. It is hoped that the effects of these preparations will, in time, be of longer duration. 


\section{Bibliografía}

1. Blitzer A, Sulica L. Botulinum toxin: basic science and clinical uses in otolaryngology. Laryngoscope 2000;111:218-26.

2. Scott A. B. Botulinum toxin injection into extraocular muscles as an alternative to strabismus surgery. Ophthalmology 1980;87:1044-9.

3. Carruthers A. History of the clinical use of botulinum toxin A and B. Clin Dermatol 2003;21:469-72.

4. Blasi J, Chapman ER, Link E. Botulinum neurotoxin A selectively cleaves the synaptic protein SNAP-23. Nature 1993;365:160-3.

5. Schiavo G, Benfenati F, Poulain B, y cols. Tetanus and botulinum B neurotoxins block neurotransmitter release by proteolytic cleavage of synaptobrevin. Nature 1992;359:832-5.

6. Borodic GE. Ferranter: effects of repeated botulinum toxin injections on orbicularis oculi muscle. / Clin Neuroophthalmol 1992;12:121-7.

7. Matarasso A, Deva AK. Botulinum toxin, safety and efficacy report. Plast Reconstr Surg 2002;109:1191.

8. Brin MF: Botulinum toxin therapy: basic sciences and overview of other therapeutic applications. En: Blitzer A, Binder WJ, Boyd JB, Carruthers A, eds. Management of Facial Lines and Wrinkles. Philadelphia, Lippincot Williams \& Wilkins 2000; pp. 279-302.

9. Lowe N. J. Botulinum toxin type A for facial rejuvenation: United States and United Kingdom perspectives. Dermatol Surg 1998;24:1216.

10. Cobb DB, Watson WA, Fernandez MC. Botulism-like syndrome after injections of botulinum toxin. Vet Hum Toxico 2000;142:163.

11. Bakheit AM, Ward CD, Mc Lellan DL Generalized botulism-like syndrome after intramuscular injection of Botulinum toxin type A: a report of 2 cases (carta). J Neurol Neurosurg Psychiatry 1997;62:198.

12. Girlanda P, Vita G, Nicolosi C. Botulinum toxin therapy: distant effects on neuromuscular transmission and autonomic nervous system. / Neurol Nerosurg Psychiatry 1992;55:844-5.

13. Carruthers A. History of the clinical use of botulinum toxin A and B. Clinics in Dermatology 2003;21:469-72.

14. Schnider P, Brichta A, Schmeid M, Auff E. Gallbladder dysfunction induced by botulinum toxin A. Lancet 1993;342:811-2.

15. Muller $C$, Wohlfarth $K$. Botulinum neurotoxin type $B$ in secondary non responders to BoNT/a. Arch Pharmacol 2002;385:R30:87.

16. Benedetto AV. Commentary: Botulinum toxin in clinical medicine. Clin Dermatol 2003;21:465-8.
17. Brin MF, Blitzer A, Herman S, Stewart C. Orofaciomandibular and lingual dystonia (Meige syndrome). En: More P, eds. Handbook of Botulinum Toxin Treatment. London, Blackwell Science, 1995; pp. 151-63.

18. Perez Atamoros F. Botulinum toxin in the lower third of the face. Clin dermatol 2003;21:505-12.

19. Excel D, Dal Forno T. Type A Botulinum toxin in the upper aspect of the face. Clin Dermatol 2003;21:488-97.

20. Moore AP, Word GD. The medical management of masseteric hypertrophy with botulinum toxin type A. Br J Oral Maxillofac Surg 1994; 32:26-8.

21. Park MY, Ahn KY, Jung DS. Botulinum toxin type $A$ treatment for contouring of the lower face. Dermatol Surg 2003;29:477-83.

22. Kim HJ, Yum K, Lee S, Heo M, Seo K. Effects of botulinum toxin A on bilateral masseteric hypertrophy evaluated with computed tomographic measurement. Dermatol Surg 2003;29:484-9.

23. Martínez-Perez D, García Ruiz-Espiga P. Recurrent temporomandibular joint dislocation treated with botulinum toxin: report of 3 cases. J Oral Maxillofac Surg 2004;62:244-6.

24. Binder W, Brin MF, Blitzer A, Schoenrock L, Diamond B. Botulinum toxin type A for migraine: an open label assessment. Mov Disord 1998;13(suppl 2):241.

25. Mathew NT, Saper JR, Silberstein SD, y cols. A multicenter double blind, placebo-controlled trial of two dosages of botulinum toxin type A in the prophylactic treatment of migraine. Neurology 1999;52(suppl 2): A256.

26. Laccourreye O, Aki E, Gutierrez-Fonseca R, Garcia D, Brasnu D, Bonan $B$. Recurrent gustatory sweating after intracutaneous injection of botulinum toxin type A: incidence, management and outcome. Arch Otolaryngol Head Neck Surg 1999;125:283-6.

27. Ellies M, Laskawi R, Rohrbach-Volland S Arglebe C. Up-to- date report of botulinum toxin therapy in patients with drooling caused by different etiologies. J Oral Maxillofac Surg 1948, 2000;61:454-7.

28. Shaari CM, Sanders I, Wu BL, Biller HF. Rhinorrhea is decreased in dogs alter nasal application of Botulinum toxin. Otolaryngol Head and Neck Surg 1995; 112:566-71.

29. Gassner HG, Sherris DA, Otley CC. Treatment of facial wounds with botulinum toxin A improves cosmetic outcome in Primates. Plast Reconstr Surg 1948, 2000;105. 